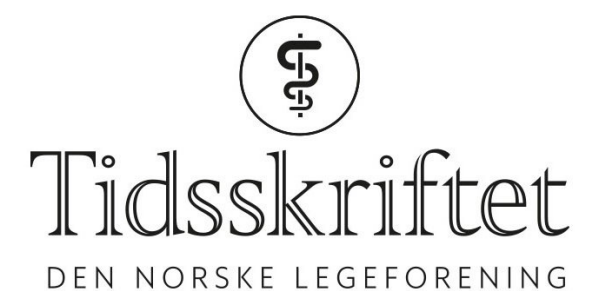

DEN NORSKE LEGEFORENING

\title{
Barn på legevakt med ørebetennelse etter innføring av pneumokokkvaksinen
}

KORT RAPPORT

HOGNE SANDVIK

E-post: hogne.sandvik@uib.no

Nasjonalt kompetansesenter for legevaktmedisin

NORCE Norwegian Research Centre

og

Morvik legekontor

Bergen

Hogne Sandvik er dr.med., spesialist i allmennmedisin, forsker og fastlege.

Forfatteren har fylt ut ICMJE-skjemaet og oppgir ingen interessekonflikter.

\section{BAKGRUNN}

Ørebetennelse er en hyppig lidelse blant små barn og medfører betydelig antibiotikabruk. Den vanligste bakterielle årsaken er pneumokokker. Pneumokokkvaksine ble innført i barnevaksinasjonsprogrammet i Norge i 2006. Hensikten med studien var å undersøke om denne vaksineringen kan ha ført til færre tilfeller av ørebetennelse på legevakt.

\section{MATERIALE OG METODE}

Materialet består av data fra alle elektroniske regningskort fra legevaktleger i perioden 2006-18. Det ble beregnet årlige konsultasjonsrater på legevakt for barn i alderen o-5 år, både totalt og på grunn av ørebetennelse. Samtidig ble vaksinasjonsdekningen i samme aldersgruppe registrert fra 2006 og fremover.

\section{RESULTATER}

Den totale konsultasjonsraten falt fra 674 per 1000 innbyggere i 2006 til 502 i 2018 (relativ reduksjon $26 \%$ ). Konsultasjonsraten for ørebetennelse ble redusert fra 44 per 1000 innbyggere til 21 (relativ reduksjon $52 \%$ ). Mens den totale raten falt jevnt gjennom hele perioden, begynte reduksjon i konsultasjonsrate for ørebetennelse å falle fra 2011, da vaksinasjonsdekningen i barnegruppen var over 9o \%.

\section{FORTOLKNING}

Pneumokokkvaksinen kan ha ført til redusert forekomst av ørebetennelse hos barn som besøkte legevakt. 
Akutt mellomørebetennelse er en hyppig årsak til at små barn bringes til lege og legevakt (1). Det er også en hyppig årsak til bruk av antibiotika hos små barn. Dersom forebyggende tiltak kunne redusere forekomsten av ørebetennelser, ville en også oppnå redusert bruk av antibiotika blant barn.

Ørebetennelser skyldes ofte virus, mens pneumokokker er den vanligste bakterielle årsaken (2). Det er utviklet vaksiner mot pneumokokksykdom, og slike vaksiner er vist å være virksomme mot ørebetennelser forårsaket av de serotypene som finnes i vaksinen (3). Etter at slike pneumokokkvaksiner ble innført i USA, har man sett en nedadgående trend i forekomsten av ørebetennelser (4).

I Norge ble pneumokokkvaksine innført i barnevaksinasjonsprogrammet i 2006, først i form av en syvvalent vaksine $\left(\mathrm{PKV}_{7}\right)$, deretter en trettenvalent vaksine ( $\left.\mathrm{PKV}_{13}\right)$ fra april 2011. Vaksinen gis ved tre, fem og tolv måneders alder. Vaksinasjonsdekningen har de senere årene vært 91-95\% (5). Fra 2006 til 2011 har dermed en gradvis økende andel av 0-5-åringene blitt vaksinert. Siden 2011 har vaksinasjonsdekningen i denne barnegruppen stabilisert seg over $90 \%$.

Hensikten med denne studien var å kartlegge årlig konsultasjonsrate på legevakt for barn 0-5 år med ørebetennelse i tidsrommet 2006-18. Det var videre et mål å vurdere om endringer i konsultasjonsrate kan ha sammenheng med bruk av pneumokokkvaksinen.

\section{Materiale og metode}

Materialet består av data fra alle elektroniske regningskort som ble levert av legevaktleger i perioden 2006-18, tidligere brukt i utarbeidelse av Årsstatistikk fra legevakt (1). Anonymiserte datafiler ble utlevert fra Helfo/Kontroll og utbetaling av helserefusjoner (KUHR).

Konsultasjoner og sykebes $\varnothing \mathrm{k}$ (takstkodene $2 \mathrm{ad}$, 2ak, $2 \mathrm{fk}$, 11ad eller 11ak, heretter benevnt som konsultasjoner) er registrert for barn o-5 år. Konsultasjoner på grunn av akutt mellomørebetennelse er karakterisert ved ICPC-2 diagnosekode H71.

Vaksinasjonsdekningen er hentet fra Nasjonalt vaksinasjonsregister (SYSVAK) (5). Her er det for hvert år oppgitt andel toåringer som har blitt fullvaksinert mot pneumokokksykdom. Slike tall finnes fra og med år 2008 og omfatter da i all hovedsak barn som ble vaksinert i 2006. I denne studien har jeg valgt å bruke det årstallet barnet ble vaksinert, slik at vaksinasjonsdata er oppgitt for årene 2006-16. Vaksinasjonsdekningen vil med dette bli noe overestimert, siden mange barn har fått sine vaksiner over to påfølgende år. Ettersom pneumokokkvaksinering ble innført i 2006, vil de fem første årsklassene ha blitt vaksinert i 2011.

Årsstatistikken for legevakt har blitt vurdert av personvernansvarlig i Nav og personvernombudet for forskning (1). Siden det ikke er mulig å identifisere enkeltpersoner i materialet, verken direkte eller indirekte, er prosjektet ikke underlagt meldeplikt etter personopplysningsloven.

Materialet omfatter alle elektroniske regningskort og representerer ikke et utvalg. De påviste forskjellene er derfor reelle og ikke beheftet med statistisk usikkerhet. Data presenteres derfor uten konfidensintervall, og det er ikke utført statistiske tester.

\section{Resultater}

En oversikt over alle konsultasjoner for barn i alderen 0-5 år er vist i figur 1.

Konsultasjonsraten har falt fra 674 per 1000 innbyggere i 2006 til 502 i 2018, en relativ reduksjon på $26 \%$. 


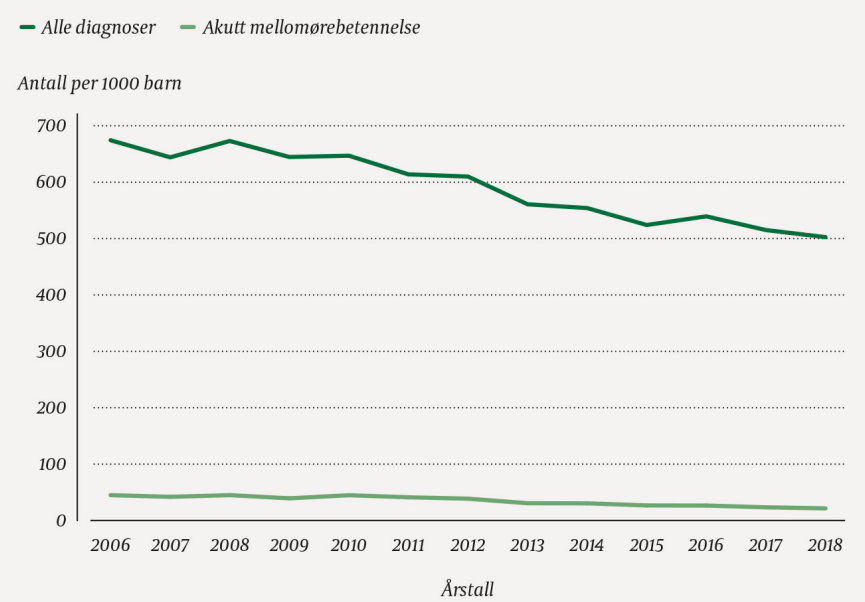

Figur 1 Konsultasjonsrater med alle diagnoser på legevakt for barn o-5 år i perioden 2006-18.

Figur 2 viser tilsvarende konsultasjonsrater for ørebetennelse. Her har raten avtatt fra 44 per 1 ooo innbyggere i 2006 til 21 i 2018, en relativ reduksjon på $52 \%$. Hele denne reduksjonen har skjedd etter 2010. Figur 2 viser også vaksinasjonsdekningen i den aktuelle barnegruppen, stigende gradvis fra $15 \%$ i 2006 til over $90 \%$ fra 2011 og utover.

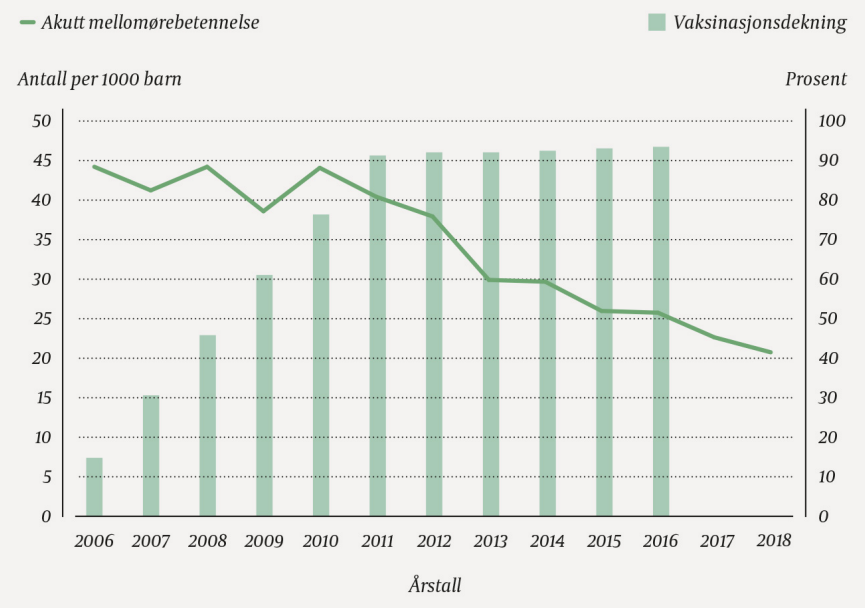

Figur 2 Konsultasjonsrater på legevakt for barn o-5 år i perioden 20o6-18 med diagnose akutt mellomørebetennelse. Etikettene viser for hvert år hvor stor andel (prosent) av hele gruppen som var vaksinert mot pneumokokker. I denne perioden var det i gjennomsnitt 364100 barn i aldersgruppen $0-5 \stackrel{\circ}{a}$.

\section{Diskusjon}

Denne studien viser at det over tid har vært en avtakende konsultasjonsfrekvens for små barn på legevakt. Reduksjonen i kontakter på grunn av ørebetennelse har imidlertid vært dobbelt så sterk som for alle årsaker. Videre er det tydelig at det kom en sterkere reduksjonen i kontakter på grunn av ørebetennelse da den aktuelle barnegruppen var fullvaksinert mot pneumokokksykdom.

Det er indikasjoner på at legesøkning på grunn av ørebetennelse har vært avtakende helt siden midten av 1990-årene, i alle fall om man teller antall otitter som andel av alle $\emptyset$ rediagnoser hos allmennlege $(2,6)$. Barn blir i mindre grad enn tidligere utsatt for passiv røyking, noe som kan bidra til redusert forekomst av ørebetennelse (7). Det har vært økende fokus på bruk av antibiotika og antibiotikaresistens, og det er mulig at foreldre i større grad velger en vent-og-se-strategi før de kontakter lege. En annen mulig forklaring på redusert bruk av legevakt kan ellers være at man i økende grad bruker helprivate legetjenester. Det har ikke vært økende bruk av fastlege i denne aldersgruppen de senere årene (8), men det er 
likevel mulig at en større andel av otittpasientene oppsøker fastlege i stedet for legevakt.

Alle disse alternative forklaringene kan bidra til å forklare redusert bruk av legevakt, men de kan neppe forklare trendbruddet i forekomsten av ørebetennelse som vi ser fra 2011 (figur 2). Her fremstår vaksinasjonsdekningen som en mulig forklaring. Den sterke nedgangen i konsultasjoner på grunn av otitt fortsetter imidlertid i årene etter at vaksinasjonsdekningen i aldersgruppen o-5 år har stabilisert seg over 9o \%. Dette kan ha sammenheng med ytterligere beskyttelse som følge av flokkimmunitet når også eldre barn er immunisert.

Det er tidligere publisert en norsk studie som har sett på sammenhengen mellom pneumokokkvaksinering og ørebetennelse hos små barn (9). Denne studien omfattet barn som var inkludert i Den norske mor, far og barn-undersøkelsen (MoBa), og hyppigheten av $\emptyset$ rebetennelser var basert på mors opplysninger. Man fant her at fullvaksinerte barn i alderen 12-18 måneder hadde $14 \%$ redusert risiko for ørebetennelse enn uvaksinerte.

På legevakt er det en lege som stiller diagnosen, og en må gå ut fra at dette er en mer valid diagnose enn retrospektive opplysninger basert på mors hukommelse. En nylig publisert artikkel fra norsk allmennpraksis tyder på at regningskortenes diagnoser har brukbar validitet (10).

\section{Konklusjon}

Siden 2010 har legevaktkonsultasjoner på grunn av ørebetennelse blant små barn blitt mer enn halvert. Uten at man kan konkludere med noen kausal sammenheng, sammenfaller dette med at den aktuelle barnegruppen var fullvaksinert mot pneumokokksykdom fra 2011.

\section{HOVEDFUNN}

Fra 2006 til 2018 avtok den totale konsultasjonsraten på legevakt for barn o-5 år med $26 \%$.

Fra 2010 til 2018 avtok konsultasjonsraten på grunn av ørebetennelser med $52 \%$.

Nedgangen i antall ørebetennelser startet da minst $90 \%$ av barna var vaksinert mot pneumokokker.

\section{LITTERATUR:}

1. Sandvik H, Hunskår S, Blinkenberg J. Årsstatistikk fra legevakt 2018. Rapport nr. 2-2019. Bergen: Nasjonalt kompetansesenter for legevaktmedisin, NORCE Norwegian Research Centre, 2019. http://bora.uib.no/handle/1956/19421 Lest 14.1.2020.

2. Hunskår S. red. Allmennmedisin. Oslo: Gyldendal Norsk Forlag, 2013.

3. Eskola J, Kilpi T, Palmu A et al. Efficacy of a pneumococcal conjugate vaccine against acute otitis media. N Engl J Med 2001; 344: 403-9. [PubMed][CrossRef]

4. Marom T, Tan A, Wilkinson GS et al. Trends in otitis media-related health care use in the United States, 2001-2011. JAMA Pediatr 2014; 168: 68-75. [PubMed][CrossRef]

5. Folkehelseinstituttet. Norgeshelsa statistikkbank. http://www.norgeshelsa.no/ Lest 14.1.2020.

6. Hunskår S. red. Allmennmedisin. Klinisk arbeid. Oslo: Ad Notam Gyldendal AS, 1997.

7. Alpert HR, Behm I, Connolly GN et al. Smoke-free households with children and decreasing rates of paediatric clinical encounters for otitis media in the United States. Tob Control 2011; 20: 207-11. [PubMed][CrossRef]

8. Statistisk sentralbyrå. Allmennlegetjenesten. https://www.ssb.no/statbank/list/fastlegetj Lest 14.1.2020. 
9. Magnus MC, Vestrheim DF, Nystad W et al. Decline in early childhood respiratory tract infections in the Norwegian mother and child cohort study after introduction of pneumococcal conjugate vaccination. Pediatr Infect Dis J 2012; 31: 951-5. [PubMed][CrossRef]

10. Sporaland GL, Mouland G, Bratland B et al. Allmennlegers bruk av ICPC-diagnoser og samsvar med journalnotatene. Tidsskr Nor Legeforen 2019; 139. doi:10.4045/tidsskr.18.0440. [PubMed][CrossRef]

Publisert: 24. mars 2020. Tidsskr Nor Legeforen. DOI: 10.4045/tidsskr.19.0727

Mottatt 11.11.2019, første revisjon innsendt 14.1.2020, godkjent 3.2.2020.

(C) Tidsskrift for Den norske legeforening 2020. Lastet ned fra tidsskriftet.no 